\title{
INVESTIGATION OF GLUTHATIONE S-TRANSFERASE VARIANTS IN A HEALHT POPULATION IN GOIÂNIA-GO
}

\author{
Lucas Carlos Gomes Pereira ${ }^{\mathrm{a}}$, Nádia Aparecida Bérgamo ${ }^{\mathrm{a}}$, Angela Adamski da Silva \\ Reis $^{\text {b }}$, Carlos Eduardo Anunciação ${ }^{\mathrm{b}}$, Elisangela de Paula Silveira-Lacerda ${ }^{\mathrm{a}}$
}

a Laboratório de Genética Molecular e Citogenética, Instituto de Ciências Biológicas, Universidade Federal de Goiás, CEP: 74690-900, Goiânia/GO, Brazil

b Laboratório de Genética Molecular, Instituto de Ciências Biológicas, Universidade Federal de Goiás, CEP: 74690-900, Goiânia/GO, Brazil

\begin{abstract}
Genetic polymorphisms in glutathione S-transferases (GSTs) genes might influence the detoxification activities of the enzymes predisposing individuals to a lot of disiases. Owing to the presence of these genetic variants, inter-individual and ethnic differences in GSTs detoxification capacity have been observed in various populations. Therefore, the present study was performed to determine the prevalence GSTMI*0/*0, GSTTI $* 0 / * 0$ and GSTP1 Ile105Val polymorphisms in 100 healthy individuals from Goiânia - GO. GSTM1 and GSTT1 polymorphisms were analyzed by a Multiplex-PCR approach, whereas GSTP1 polymorphisms were examined by PCR-RFLP. The frequencies of GSTMI and GSTT1 *0/*0 genotypes are $49 \%$ and $31 \%$, respectively. The frequencies of GSTP1 Ile/Ile, Ile/Val, and Val/Val genotypes were 40\%, 53\%, and 7\%, respectively. The wild-type (Ile) and variant (Val) allele frequencies were $66.5 \%$ and $33.5 \%$, respectively. The combined genotypes distribution of GSTM1, GSTT1 and GSTP1 polymorphisms showed 12 possible genotypes present in our population; seven of them have a frequency greater than $5 \%$. The effect of combined genotypes of these GSTs polymorphisms is still unknown. These findings in healthy population, give us such more information for the future epidemiological and clinical studies. Using to examine the effect of these combinations in drugs metabolism and cancer predisposition, further largest group would be needed, since their frequencies are quite low. To our of GSTs polymorfisms, this is the first study indicating the frequencies of genetic polimorphisms of GST superfamily in a health population in a Goiania population.
\end{abstract}

Keywords: Glutathione S-transferase, Genetic polymorphism, health population 


\section{Introduction}

Individual inherited genetic differences related to polymorphism in detoxification enzymes could be an important factor not only in metabolism but also in predisposition to pathologic condition [1]. Functional genetic polymorphisms have been described for Glutathione-S-transferase (GSTS) genes, a superfamily of phase II metabolizing enzymes. GSTs catalyze the conjugation of reduced glutathione (GSH) to a wide variety of electrophilic compounds in order to make them more soluble enabling their elimination [2]. As a result of this detoxification activity, GSTs protect the cell from DNA damage, genomic instability and cancer development. In addition, as nonenzymatic proteins, GSTs can modulate signaling pathways that control cell proliferation, cell differentiation and apoptosis, among other processes [3,4]. Deletion polymorphisms of GSTM1 and GSTT1 genes and the single nucleotide polymorphism in GSTP1 c.319A > G (rs1695; p.105Ile > Val) lead to the absence or reducion of the detoxification capacity of the enzyme. Differences in GSTs activity may modify the risk of cancer development and also may impact on the heterogeneous responses to toxic substances or specific therapies [2]. Moreover, GST polymorphisms are known to contribute to inter-individual and ethnic variability in the susceptibility to environmental risk factors, cancer predisposition and drug responsiveness. Several epidemiological studies evaluated the role of GST polymorphisms on CML susceptibility, but conflicting results have been achieved [5,6]. There are no data available on these polymorphisms in the Goiania health population. The aim of the present study was to determine the prevalence of GST polymorphisms in the health population in Goiânia, a city located in the center of the west of Brazil, and to compare the results with different populations described in the literature.

\section{Methods}

\subsection{Subjects}

This study was carried out in the Genetic Molecular and Citogenetic Laboratory of the Institute of Biological Science I at Federal University of Goias, Goiânia, Brazil. The study was performed according approved by the ethics committee of Federal University of Goias (approval CEP: 895.552). In the current survey, 100 patients (35M/65F) of 
both genders and aged 18-90 (M: 30.2) years old considered healthy and practicing physical activity 2 to 3 times a week, were enrolled after receiving their informed consent.

\subsection{Sample collection and DNA analyzes}

Peripheral blood $(5 \mathrm{~mL})$ was collected in EDTA vacutainer tubes from all participating individuals after obtaining their written consent. Until the DNA extraction blood DNA collections was store a $-20^{\circ} \mathrm{C}$. Genomic DNA extraction was performed from whole blood using a Purelink Genomic DNA Kit (Invitrogen, Life Technologies Inc.; USA) and the concentration was measured using a NanoDrop ${ }^{\text {TM }}$ 2000/2000c Spectrophotometers (Thermo Scientific, USA).

\subsection{Genotyping}

GSTM1 and GSTT1 polymorphism analyses were performed by multiplex polymerase chain reaction (PCR Applied Biosystems Veriti 9902, 96 Well Thermal Cycler), previously suggested by Abdel-Rahma, et al., [7], and modified by Reis, et al., [8], with the ubiquitous RH92600 gene as an internal standard. This was carried out amplification using the following primers: GSTT1 forward primer 5 - TTC CTT ACT GGT CCT CAC ATC TC - 3`; GSTT1 reverse primer 5` TCA CCG GAT CAT GGC CAG CA 3`; GSTM1 forward primer 5`-GAA CTC CCT GAA AAG CTA AAG C - 3`; and GSTM1 reverse primer 5 - GTT GGG CTC AAA TAT ACG GTG G - 3`. Each $25 \mu \mathrm{L}$ PCR reaction contained $2.5 \mu \mathrm{L}$ of $10 \mathrm{X}$ reaction buffer (Tris- $\mathrm{HCl} 10 \mathrm{mM} \mathrm{pH} 8.3$ and $\mathrm{KCl}), 2 \mathrm{mM} \mathrm{MgCl}_{2}, 200 \mu \mathrm{M}$ each of deoxynucleoside triphosphates, 10pmol of each primer, 1 unit of Platinum Taq DNA polymerase (Invitrogen, Carlsbad, CA, USA), and 100ng genomic DNA. Thermal cycling conditions for the PCRs were as follows: $15 \mathrm{~min}$ at $95^{\circ} \mathrm{C}$, followed by 30 cycles of $95^{\circ} \mathrm{C}$ for $2 \mathrm{~min}, 60^{\circ} \mathrm{C}$ for $1 \mathrm{~min}$, and $72^{\circ} \mathrm{C}$ for $1 \mathrm{~min}$, with a final extension at $72^{\circ} \mathrm{C}$ for $10 \mathrm{~min}$. PCR products were visualized on a $2 \%$ agarose gel electrophoresis at $100 \mathrm{~V}$ for $50 \mathrm{~min}$. Them the spected was confirmed two amplification bands, 480bp bands for GSTT1 and 215bp for GSTM1 were obtained for the GSTT1+/GSTM1+ genotype. GSTT1+/GSTM1- genotype showed one band of 480bp, and the GSTT1-/GSTM1+ genotype showed a band of 215bp. For the GSTT1/GSTM1- genotype (designated as null genotype), no bands were obtained. 
GSTP1 polymorphism analyses were performed by RFLP-PCR and the presence of $176 \mathrm{pb}$ DNA fragment in the samples were made using polyacrylamide gel that was stained with silver solution $4 \mathrm{~g} \mathrm{~L}^{-1}$. After confirmed the amplification of $176 \mathrm{bp}$ band in all samples, the PCR product was restricted with the use of Alw26I (Synapse) enzyme according to the manufacturer's suggested protocol for subsequent genotyping. Thermocycling was 12 hours at $37{ }^{\circ} \mathrm{C}$ followed by 20 minutes at $65{ }^{\circ} \mathrm{C}$. The Alw26I restriction enzyme recognizes the DNA the GTCTC codon site at which occurs the exchange of the nucleotide adenine for guanine (occurring replacing the isoleucine amino acid at valine amino acid), and acts by cutting the DNA into two fragments of 91 and $85 \mathrm{bp}$, when there is the polymorphism.

\subsection{Statistical analysis}

The allelic and genotypic frequencies of the population were calculated using software Excel and expressed as a percentage. Fisher's exact test was performed using software GraphPad prism version 7.00 for Windows, GraphPad Software, California USA.

\section{Results}

\subsection{GSTM1 and GSTT1 deletion polymorphisms}

In the current study, the frequencies of three polymorphisms in GSTs genes on individuals in a health population in Goiânia have been studied. The genotype distributions and allele frequencies observed in this study are shown in Table 1. We couldn't calculate the expected Hardy-Weinberg frequencies for GSTM1 and GSTT1 genotypes, as multiplex-PCR approach cannot differentiate between the wild-type $(* 1 / * 1)$ and heterozygous $(* 0 / * 1)$ genotypes. The GSTM1 and GSTT1 deletion polymorphisms were analyzed by Multiplex-PCR approach, using Rh92600 as an internal control. As shown in Table 1 , the frequencies of GSTM1 and GSTT1 *0/*0 genotypes are $49 \%$ and $31 \%$, respectively.

\subsection{GSTP1 Ile105Val polymorphism}

The GSTP1 Ile 105Val polymorphism was performed by PCR-RFLP. As shown in Table 2, the frequencies of GSTP1 Ile/Ile, Ile/ Val, and Val/Val genotypes were 40\%, 53\%, and 
$7 \%$, respectively. The wild-type (Ile) and variant ( Val) allele frequencies were $66.5 \%$ and $33.5 \%$, respectively (table 2 ).

\subsection{Combined genotype analysis}

The distribution of combined genotype of GSTM1, GSTT1 and GSTP1 polymorphisms showed the possible genotypes are present in a health population from Goiânia. Among these, seven genotype combinations showed frequency greater than 5\%. The most frequently observed combinations were null M1/ non-null T1/ Ile/Val (20\%), non-null M1/ non-null T1/ Ile/Ile (15\%), non-null M1/ non-null T1/ Ile/Val (15\%) and null M1/ non-null T1/ Ile/Ile (14\%) (Table 3).

\section{Discussion}

The result for GSTMI and GSTT1 deletion polymorphisms concerning the GSTMI*0/*0 and $G S T T 1 * 0 / * 0$ genotype was $49 \%$ and $31 \%$. This is an agreement with previous report of Kubiszeski et al. [9] in Cuiabá population (50\% and 32\%), and Rocha et al. [10] in Amazônia population. Other studies in the Brazilian population from Bahia, performed by Rocha et al. [10], and Pinhel, et al. [11] in the population from São Paulo confirm our findings in the Goiânia population. GSTM1 and GSTT1 enzymes metabolize several precarcinogens, drugs, constituents of tobacco smoke and solvents to reactive metabolites which ultimately lead to DNA or protein damage [12]. Hence, the data on the prevalence of this polymorphism will help in predicting susceptibility to various cancers.

The results for GSTP1 Ile105Val polymorphism are similar to those reported in São Paulo population (n 53), in which the wild-type (Ile) and variant (Val) allele frequencies were $67 \%$ and $33 \%(P=1,000)$, respectively [13] and in Rio de Janeiro population (n 531) with $69 \%$ and $31 \%(P=0,7628)$ respectively [14], both studies with health people.

Regarding to the other ethnic groups, Goiânia population showed a similar prevalence of GSTP1 Ile105Val with those reported in some Asian populations such as, Chinese, Indian, Tunisian and venezuelan $[12,15,16,17,18,19]$ as well as with White Americans and South Africans [20, 21]. Interestingly, Goiânia population showed a significantly high prevalence of GSTP1 Ile105Val polymorphism than that reported in Japanese population, in which the wild-type (Ile) and variant (Val) allele frequencies 
were $84 \%$ and $16 \%(P=0,0081 *)$, respectively [21] and the Korean population with $80,9 \%$ and $19,1 \%$, respectively $\left(P=0,0355^{*}\right)[22]$.

The importance of this class of enzymes and, in a general way, of all the enzymes of the GST family has been increasingly highlighted by its relation in several processes of metabolism and catalytic properties and of detoxification besides having discovered other biologically important functions as, for example, in protein-protein interactions; involvement with chaperones and mechanisms of kinases; and especially myeloproliferative properties [23].

GSTP1 is a major enzyme metabolizing anti cancer drugs like oxiplatin, cyclophosphamide which are used in the treatment of breast cancer and colorectal cancer [24]. An over expression of this enzyme in individuals with Ile/Ile genotype causes resistance to drugs like cisplatin [25, 26]. Therefore, investigation of this polymorphism will provide a clue to the identification of responders to cancer therapy with certain chemotherapeutic drugs.

Regarding the effects of the combined genotypes, some published reports showed that single GST gene polymorphism does not significantly increase risk to cancer [27], suggesting that investigations on combined genotypes of GSTM1, GSTT1 and GSTP1, or even in relation to other metabolizing enzymes are needed. Additionally, some other studies have reported a relationship between the combination of GSTM1, GSTT1, and GSTP1 genotypes and the risk of various diseases, such as chronic lymphocytic leukemia, thyroid cancer and they suggested a possible synergistic effect between GST genotypes $[28,29]$.

Genetic polymorphisms of GSTs genes differ significantly among racial groups and residential populations in different parts of the world [30,31]. Based on our findings, Goiânia population showed an, eventual, similarity with others Brazilian populations for genotype and allele frequencies of GSTM1, GSTT1, GSTP1 polymorphisms.

The obstacle with research using the Brazilian population is that it resulted basically from the racial mixture between whites from the Iberian Peninsula and Africans of various ethnical groups, with a small contribution by native Amerindians. However, this may also represent the lack of a rigid distinction between races and the intense admixture that has been occurring in this country [32]. 
Studies, including the present one, indicate that while evaluating the role of a particular GST gene in any disease susceptibility, the whole pattern of different biotransformation enzymes should be considered. Wormhoudt et al.,[33] explains this is because multiple detoxification enzymes may be involved in the metabolism of a given compound and the resulting metabolites may produce different effects clinically.

The effect of combined genotypes of these GSTs polymorphisms is still unknown. These findings in healthy population, give us such more information for the future epidemiological and clinical studies. Using to examine the effect of these combinations in drugs metabolism and cancer predisposition, further largest group would be needed, since their frequencies are quite low.

\section{Conclusion}

This study provides the first results of genotype distribution and allele frequencies of GSTs $M 1, T 1$ and $P 1$ polymorphisms in a health population in Goiânia - GO. An identifier of polymorphisms related to predisposition may contribute to the implementation of a public health policy focused on preventive medicine. Hence, it opens up new avenues for further investigations by epidemiologists in determining inter individual variation in genetic susceptibility to various diseases caused due to geneenvironment interaction.

\section{References}

[1]. BHATTACHARJEE, S.; ZHAO, Y.; HILL, J. M.; CULICCHIA, F.; KRUCK, T. P.; PERCY, M. E.; et al. Selective accumulation of aluminum in cerebral arteries in Alzheimer's disease. J. Inorg. Biochem. 126, 35-37. 2013.

[2]. SHARMA, A.; PANDEY, A.; SHARMA, S.; CHATTERJEE, I.; MEHROTRA, R.; SEHGAL, A.; SHARMA. J.K. Genetic polymorphism of glutathione S-transferase P1 (GSTP1) in Delhi population and comparison with other global populations. Meta Gene, 134-142, 2014.

[3]. WANG, G.; ZHANG, L.; LI, Q. Genetic polymorphisms ofGSTT1, GSTM1, andNQO1 genes and diabetes mellitus risk in Chinese population. Biochem. Biophys. Res. Commun. 341, 310-313. 2006. 
[4]. ZHANG, J.; LIU, H.; YAN, H.; HUANG, G.; WANG, B., Null genotypes of GSTM1 and GSTT1 contribute to increased risk of diabetes mellitus: a meta analysis. Gene 518: 405-11. 2013.

[5]. IAFRATE, A.J.; FEUK, L.; RIVERA, M.N.; LISTEWNIK, M.L.; DONAHOE, P.K.; QI, Y.; SCHERER, S.W.; LEE, C., Detection of large-scale variation in the human genome. Nat Genet 36:949-951. 2004.

[6]. SEBAT, J.; LAKSHMI, B.; TROGE, J.; ALEXANDER, J., et al., Large-scale copy number polymorphism in the human genome. Science 305:525-528. 2004.

[7]. ABDEL-RAHMAN, S.Z.; EL-ZEIN, R.A.; et al., A multiplex PCR procedure for polymorphic analysis of GSTM1 and GSTT1 genes in population studies. Cancer lett.10: 229-233. 1996.

[8]. REIS, A.A.S.; SILVA, D.M.; CURADO, M.P.; DA CRUZ, A.D., Involvement of CYP1A1, GST, 72TP53 polymorphisms in the pathogenesis of thyroid nodules. Genet. Mol. Res. 9 (4): 2222-2229. 2010.

[9]. KUBISZESKI, E.H.; DE MEDEIROS, S.F.; DA SILVA SEIDEL, J.A.; BARBOSA, J.S., et al. Glutathione S-transferase M1 and T1 gene polymorphisms in Brazilian women with endometriosis. J. Assist. Reprod. Genet.32: 1531-1535. 2015.

[10]. ROCHA, A.V.; CARDOSO, B.R.; ZAVARIZE, B.; et al., GPX1 Pro198Leu polymorphism and GSTM1 deletion do not affect selenium andmercury status in mildly exposed Amazonian women in an urban population. Science of the Total Environment 571, 801-808. 2016.

[11]. PINHEL, M.A.S; SADO, C.L.; LONGO, G.S. et al., Nullity of GSTT1/GSTM1 related to pesticides is associated with Parkinson's disease. Arq Neuropsiquiatr. 71(8):527-532, 2013.

[12]. SALAH, G.B. et al., Polymorphisms of glutathione S-transferases M1, T1, P1 and A1 genes in the Tunisian population: An intra and interethnic comparative approach. Gene 498, 317-322. 2012. 
[13]. BARBERINO, W. M; OLIVEIRA, R. G.; TEIXEIRA, V. U., et al.. Polimorfismos GSTM1, GSTT1 e GSTP1 da enzima Glutationa S-transferase como fatores moduladores do fenótipo na anemia falciforme . Mutation research, 2014.

[14]. ROSSINI, A., et al., Frequencies of GSTM1, GSTT1 and GSTP1 polymorphisms in a Brazilian population. Genet. Mol. Res. 1, 233-240. 2002.

[15]. MISHRA, D.K.; KUMAR, A.; SRIVASTAVA, D.S.; MITTAL, R.D. Allelic variation of GSTT1, GSTM1 and GSTP1 genes in North Indian population. Asian Pac. J. Cancer Prev. 5, 362-365. 2004.

[16]. WANG, J.; DENG, Y.; CHENG, J.; DING, J.; TOKUDOME, S. GST genetic polymorphisms and lung adenocarcinoma susceptibility in a Chinese population. Cancer Lett. 201, 185-193. 2003.

[17]. CHELBI, H.; LACHHEB, J.; AMMAR, J.; HAMZAOUI, K.; HAMZAOUI, A. Association of GST genes polymorphisms with asthma in Tunisian children. Mediators Inflamm. 2007.

[18]. LAKHDAR, R.; DENDEN, S.; KNANI, J.; LEBAN, N.; DAIMI, H.; HASSINE, M.; LEFRANC, G.; CHIBANI, J. B.; KHELIL, A. H.. Microsomal epoxide hydrolase gene polymorphisms and susceptibility to chronic obstructive pulmonary disease in the Tunisian population. Genet. Test Mol. Biomarkers 14, 857-863. 2010.

[19]. CHIURILLO, M.A.; GRIMAN, P.; SANTIAGO, L.; TORRES, k.; MORAN, Y.; BORJAS, L. Distribution of GSTM1, GSTT1, GSTP1 and TP53 disease-associated gene variants in native and urban Venezuelan populations. Gene 531, 106-111. 2013.

[20]. LI, D., DANDARA, C.; PARKER, M.I. C/T polymorphism in the GSTP1 gene is associated with increased risk of esophageal cancer. BMC Genet. 11, 47. 2010.

[21]. KIHARA, M.; KIHARA, M.; NODA, K., Lung cancer risk of the GSTM1 null genotype is enhanced in the presence of the GSTP1 mutated genotype in male Japanese smokers. Cancer Lett. 137, 53-60. 1999. 
[21]. MillikAN, R.; PITTMAN, G.; TSE, C.K.; SAVITZ, D.A.; NEWMAN, B.; BELL, D., Glutathione Stransferases M1, T1, and P1 and breast cancer. Cancer Epidemiol. Biomarkers Prev. 9, 567-573. 2000.

[22]. LEE, J.Y; HWANG, I.W; LIM, M.H; et al., Association of glutathione Stransferases M1, T1 and P1 gene polymorphisms with attention deficit and hyperactivity disorder in Korean children. Gene 586, 228-233. 2016.

[23]. TEW, K.; TOWNSEND, D. Glutathione-s-transferases as determinants of cell survival and death. Antioxidants \& redox signaling. v.17, p.1728-37, 2012.

[24]. MARSH, S.; MCLEOD, H.L. Pharmacogenetics of irinotecan toxicity. Pharmacogenomics. 5:835-843. 2004.

[25]. TOWNSEND, D.M.; TEW, K.D.; TAPIERO, H. The importance of glutathione in human disease. Biomed Pharmacother. May-Jun; 57(3-4):145-55. 2003.

[26]. XU, Q.; LIN, G.; CHEN, W.J.; ZHOU, X.; LIN, L. Relation between the expression of P-gp and GST-pi in oral and maxillofacial squamous carcinoma and chemoresistance. Chinese journal of stomatology. 37, pp. 90-93. 2002.

[27]. NTAIS, C. POLYCARPOU, A., IOANNIDIS, J.P. Association of GSTM1, GSTT1, and GSTP1 gene polymorphisms with the risk of prostate cancer: A metaanalysis. Cancer Edidemiol. Biomarkres Prev. 14, 176-181. 2005.

[28]. JORGE, G.; SONIA, R.; OCTAVIA, M.G.; LSABEL, M.; TERESA, C.F.; EDWARD, L.; LUZIA, G.; JULIETA, E.P.; JOSE, R. Combined effects of glutathioneS-transferase polymorphisms and thyroid cancer risk. Cancer Genet. Cytogenet. 151, 60-67. 2004.

[29]. YUIlle, M.; CONDIE, A.; HUDSON, C.; KOTE-JARAI, Z.; STONE, E.; EELES, R.; MATUTES, E.; CATOVSKY, D.; HOULSTON, R., Relationship between glutathione S-transferase M1, T1, and P1 polymorphisms and chronic lymphocytic leukemia. Blood 99 (11), 4216-4218. 2002.

[30]. GARTE, S., GASPARI, L.; ALEXANDRIE, A.K.; AMBROSONE, C.; AUTRUP, H.; AUTRUP, J.L.; BARANOVA, H.; et al.. Metabolic gene polymorphism frequencies in control populations. Cancer Epidemiol. Biomarkers Prev. 10, 1239-1248. 2001. 
[31]. NAZAR-STEWART, V.; VAUGHAN, T.L.; STAPLETON, P.; VAN LOO, J.; NICOL-BLADES, B.; EATON, D.L., A population-based study of glutathione Stransferase M1, T1 and P1 genotypes and risk for lung cancer. Lung Cancer 40, 247258. 2003.

[32]. GATTAS, G.J.F. Kato, M.; Soares-Vieira, J.A.; Siraque, M.S.; Kohler, P.; Gomes, L.; Rego, M.A.; Bydlowski, S.P. Ethnicity and glutathione S-transferase (GSTM1/GSTT1) polymorphisms in a Brazilian population. Brazilian journal of Medical and Biological Research 37: 451-458. 2004.

[33]. WORMHOUDT, L.W.; COMMANDEUR, J.N.M.; VERMEULEN, N.P.E., Genetic polymorphism of human Neacetyltransferase, cytochrome P450, glutathioneStransferase, and epoxide hydrolase enzymes: relevance to xenobiotic metabolism and toxicity. Crit. Rev. Toxicol. 29, 59-124. 1999. 
Table 1. Distribution of genotype and allele frequencies of GSTM1 and GSTT1, polymorphisms in a health population in Goiânia.

\begin{tabular}{|c|c|c|c|c|c|c|}
\hline & \multicolumn{3}{|c|}{ Age } & \multicolumn{2}{|c|}{ Gender } & Total \\
\hline & $18-30$ & $31-50$ & $\geq 51$ & Male & Female & \\
\hline Number of Individuals & 62 & 33 & 5 & 35 & 65 & 100 \\
\hline $\begin{array}{c}\text { GSTM1 null frequency } \\
(\%)\end{array}$ & $33(0.33)$ & $14(0.14)$ & $2(0.02)$ & $15(0.15)$ & $34(0.34)$ & $49(0.49)$ \\
\hline GSTT1 null frequency $(\%)$ & $20(0.20)$ & $9 \quad(0.09)$ & $2(0.02)$ & $9 \quad(0.09)$ & $22(0.22)$ & $31(0.31)$ \\
\hline
\end{tabular}


Table 2. Genotype and allele frequencies of GSTP1 Ile105Val polymorphism of Tunisian population and various ethnic groups.

\begin{tabular}{cccc}
\hline Genotypes & $\mathrm{N}$ & \multicolumn{2}{c}{ Allele frequencies } \\
& & ILE & VAL \\
\hline ILE/ILE & 40 & & \\
$I L E / V A L$ & 53 & 0,665 & 0,335 \\
$V A L / V A L$ & 7 & & \\
\hline
\end{tabular}


Table 3. Combined genotype analysis of GSTM1, GSTT1 and GSTP1 polymorphisms.

\begin{tabular}{|c|c|c|c|c|}
\hline GSTM & $G S T T$ & $G S T P$ & \multicolumn{2}{|c|}{ Frequency } \\
\hline & & & $\mathrm{n}$ & $\%$ \\
\hline \multirow[t]{6}{*}{ Non Null } & Non Null & Ile/Ile & 15 & $(0.15)$ \\
\hline & Non Null & Ile/Val & 15 & $(0.15)$ \\
\hline & Non Null & $\mathrm{Val} / \mathrm{Val}$ & 3 & $(0.03)$ \\
\hline & Null & Ile/Ile & 4 & $(0.04)$ \\
\hline & Null & Ile/Val & 12 & $(0.12)$ \\
\hline & Null & Val/Val & 2 & $(0.02)$ \\
\hline \multirow[t]{6}{*}{ Null } & Non Null & Ile/Ile & 14 & $(0.14)$ \\
\hline & Non Null & Ile/Val & 20 & $(0.20)$ \\
\hline & Non Null & $\mathrm{Val} / \mathrm{Val}$ & 1 & $(0.01)$ \\
\hline & Null & Ile/Ile & 7 & $(0.07)$ \\
\hline & Null & Ile/Val & 6 & $(0.06)$ \\
\hline & Null & $\mathrm{Val} / \mathrm{Val}$ & 1 & $(0.01)$ \\
\hline Total & & & 100 & $100 \%$ \\
\hline
\end{tabular}

n: number of subjects.

Combined genotypes were expressed by percentage $(\%)$.

Null: homozygous deletion $(* 0 / * 0)$.

Non-null: heterozygous deletion $(* 0 / * 1)$ or wild homozygous $(* 1 / * 1)$. 